\title{
SISTEM PENDUKUNG KEPUTUSAN UNTUK MENENTUKAN JURUSAN PADA SMAN 1 BAWANG JAWA TENGAH DENGAN TOPSIS
}

\author{
Galih Pramoda Dibya Ardana ${ }^{1}$, Frisma Handayanna ${ }^{2}$ \\ Program Studi Teknik Informatika \\ Sekolah Tinggi Manajemen Informatika dan Komputer Nusa Mandiri \\ http://www.nusamandiri.ac.id \\ *1galihpramoda97@gmail.com; 2frisma.fha@nusamandiri.ac.id
}

\begin{abstract}
Abstrak
SMA Negeri 1 Bawang adalah sekolah menengah atas negeri yang berada di jawa tengah, Setiap tahunnya SMA Negeri 1 Bawang membuka penerimaan siswa baru, setiap siswa SMA Negeri 1 Bawang akan ditempatkan pada kelas jurusan sesusai bidang atau kemampuan masing-masing siswa, Salah satu contoh masalah yang penulis ambil adalah disekolah tersebut terdapat 2 jurusan yaitu IPA dan IPS yang dimana pihak sekolah mengalami kesulitan untuk menentukan jurusan setiap siswanya, karena seiring berjalannya waktu siswa yang mendaftar di SMA Negeri 1 Bawang bertambah banyak. Untuk meringankan pihak sekolah dalam menentukan jurusan siswa, maka penulis melakukan penelitian SPK menggunakan metode TOPSIS untuk membantu pihak sekolah menentukan penjurusan setiap siswanya. Dalam penelitian ini data dikumpulkan dari data sekunder dalam bentuk rekap nilai ujian nasional siswa, peneliti akan melakukan perhitungan data nilai rekap nilai ujian siswa sesuai bobot kriteria mata pelajaran, dikarenakan jumlah populasi data yang dikumpukan peneliti terlalu banyak yaitu 156 data digunakanlah rumus slovin untuk mendapatkan sampel penelitian menjadi 61 data dan software Microsoft Excel untuk menghindari kesalahan pehitungan serta mempercepat perhitungan, Hasil yang didapat dari penelitian ini adalah dari banyaknya sampel yaitu 61 data ditentukanlah bahwa 37 siswa masuk pada jurusan IPA dan 24 Siswa masuk pada jurusan IPS.
\end{abstract}

Kata kunci: Metode TOPSIS, Menentukan Jurusan, SPK

\begin{abstract}
Bawang 1 Public High School is a state high school located in Central Java. Every year SMA 1 Bawang opens new admissions, every student of Bawang 1 High School will be placed in a class according to their respective fields or abilities. One example of a problem the authors take is in the school there are 2 majors namely Science and Social Sciences where the school has difficulty in determining the direction of each student, because as time goes by students who enroll in SMA 1 Bawang increase. To relieve the school in determining the student's majors, the authors conducted SPK research using the TOPSIS method to help the school determine the direction of each student. In this study data were collected from secondary data in the form of national exam scores recap, students will calculate the value of student exam value recap according to the criteria weight of the subjects, because the population of data collected by researchers is too much, 156 data used slovin formula to get samples the study became 61 data and Microsoft Excel software to avoid accounting errors and speed up calculations. The results obtained from this study were that from the number of samples, 61 data determined that 37 students entered the science department and 24 students entered the social studies department.
\end{abstract}

Keywords: TOPSIS Method, Determining Department, SPK

\section{PENDAHULUAN}

SMA Negeri 1 Bawang adalah sekolah menengah atas negeri yang berada di jawa tengah, Setiap tahunya SMA Negeri 1 Bawang membuka penerimaan siswa baru, setiap siswa SMA Negeri 1 Bawang akan ditempatkan pada kelas jurusan sesusai bidang atau kemampuan masing-masing siswa, seiring berjalanya waktu siswa yang mendaftar di SMA Negeri 1 Bawang bertambah banyak, disekolah tersebut terdapat 2 jurusan yaitu IPA dan IPS yang dimana pihak sekolah mengalami kesulitan untuk menentukan jurusan setiap siswanya, oleh karena itu penulis melakukan penelitian SPK menggunakan metode TOPSIS (Mardiana \& Tanjung, 2019) untuk 
membantu pihak sekolah menentukan penjurusan setiap siswanya. Adapun kriteria-kriteria yang dibutuhkan dalam proses penentuan jurusan ini antara lain Nilai ujian nasional SMP siswa yang telah diajukan kepada pihak SMA sebagai syarat pendafaran sekolah.

Teknik Topsis (Trchnique for Order Preference by Similiarity to Ideal Solution) telah berjalan dengan baik dan dapat menghasilkan bobot kriteria penilaian dan informasi yang jelas dan cepat dibandingkan dengan perhitungan manual sehingga SD Negeri Kebalen 07 dapat menggunakannya sebagai alat untuk membuat keputusan yang tepat (Susliansyah et al., 2019)

Algoritma TOPSIS merupakan sebuah metode yang digunakan untuk membuat urutan ranking berdasarkan hasil perhitungan, dengan penilaian bobot kriteria yang di tentukan (Dashti et al., 2010). Jurusan siswa MAN II Yogyakarta yaitu IPA, IPS, Bahasa, dan Agama. Sistem ini dapat menentukan jurusan siswa yang tepat berdasarkan ranking dari hasil perhitungan algoritma TOPSIS dan kuota kelas (Prayoga \& Pradnya, 2017)

Metode TOPSIS diharapkan mampu menyeleksi keputusan terbaik dari beberapa keputusan yang diharapkan dalam pemberian bonus tahunan karyawan. TOPSIS menggunakan prinsip bahwa alternatif yang terpilih harus mempunyai jarak terdekat dari solusi ideal positif dan jarak terpanjang (terjauh) dari solusi ideal negatif dari sudut pandang geometris dengan menggunakan jarak Euclidean (jarak antara dua titik) untuk menentukan kedekatan relatif dari suatu alternatif (Agusli et al., 2017).

\section{METODE PENELITIAN}

Mengindentifikasi masalah dalam penentuan jurusan di SMAN 1 BAWANG. Adapun metode penelitian yang digunakan adalah:

\section{Teknik Pengumpula Data}

\section{A. Observasi}

Pada tahap observasi mendapatkan data-data dan fakta dari pengamatan langsung di SMAN 1 BAWANG.

\section{B. Wawancara}

Pada tahap wawancara mengadakan atau melakukan wawancara langsung dengan guru BK dan bagian penerimaan siswa baru, untuk mendapatkan keterangan-keterangan yang diperlukan sebagai bahan penulisan laporan seperti kriteria-kriteria apa saja untuk penentuan jurusan siswa pada sekolah SMAN 1 BAWANG.

\section{Hipotesa}

H0: Tidak adanya validitas data kriteria pada nilai siswa yang digunakan untuk menentukan jurusan yang diminati siswa dengan metode TOPSIS.

H1 : Adanya validitas data kriteria pada nilai siswa yang digunakan untuk menentukan jurusan yang diminati siswa dengan metode TOPSIS.

\section{Tahap Penelitian}

Tahapan yang dilakukan dalam penelitian ini digambarkan dalam bagan sebagai berikut:

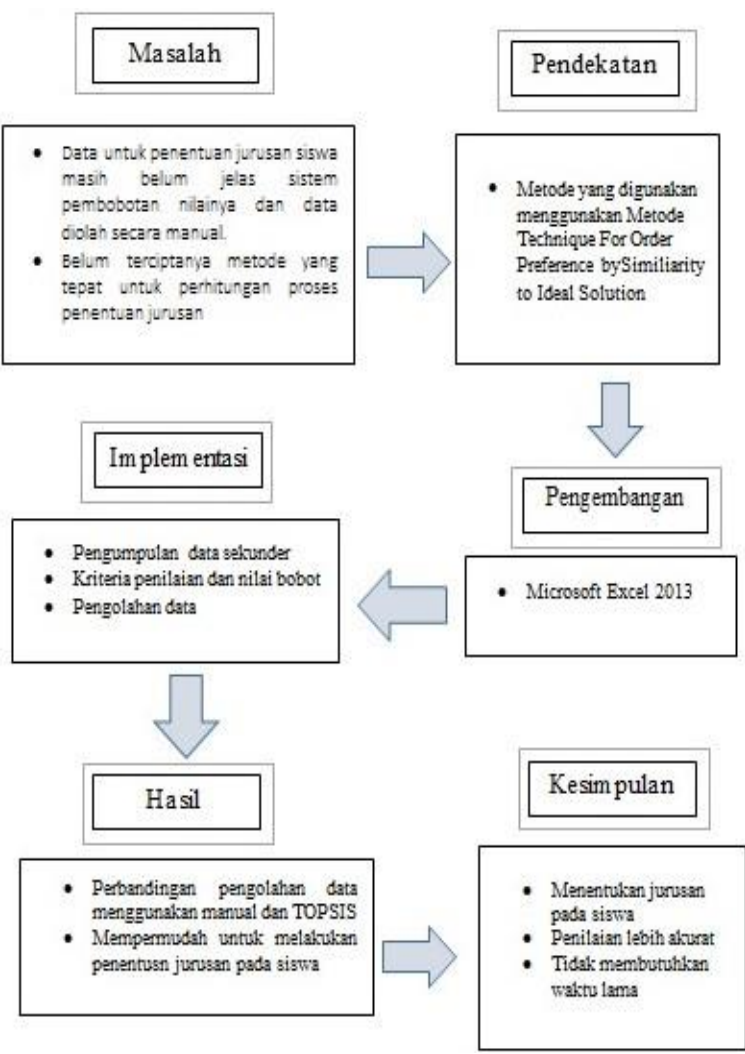

Gambar 1. Tahapan Dalam Penelitian

\section{HASIL PENELITIAN DAN PEMBAHASAN}

\section{Populasi}

Populasi merupakan wilayah generalisasi yang terdiri dari obyek/subyek yang memiliki kuantitas dan karakteristik tertentu yang ditetapkan oleh peneliti untuk dipelajari dan kemudian ditarik kesimpulannya (Siyoto \& Sodik, 2015).

Populasi juga bukan hanya sekedar jumlah yang ada pada obyek maupun subyek yang dipelajari, Populasi dalam penelitian ini adalah seluruh Siswa yang ada di SMA Negeri 1 Bawang yang berjumlah 156. Karena jumlah anggota populasi terlalu banyak, maka dapat dilakukan penentuan sampel. 


\section{Sampel}

Sampel adalah sebagian dari jumlah dan karakteristik yang dimiliki oleh populasi tersebut, ataupun bagian kecil dari anggota populasi yang diambil menurut prosedur tertentu sehingga dapat mewakili populasinya (Siyoto \& Sodik, 2015).

Untuk menentukan sampel pada penelitian ini penulis menggunakan rumus Slovin untuk menghitung jumlah sampel minimal

$n=\frac{\mathrm{N}}{1+N e^{2}}$

Keterangan:

$\mathrm{n}=$ Sampel minimal

$\mathrm{N}=$ Populasi

$\mathrm{e}=$ error margin

Penyelesainnya:

$\mathrm{n}=156 /\left(1+\left(156 \times 0,1^{2}\right)\right.$

$\mathrm{n}=156 /(1+(156 \times 0,01)$

$\mathrm{n}=156 /(1+1,56)$

$\mathrm{n}=156 /(2,56)$

$\mathrm{n}=60,93$. Jadi sampel minimalnya adalah 61

\section{Penentuan Kriteria dan Bobot Penilaian}

\section{A. Kriteria Penilaian}

Tabel 1. Kriteria Penilaian

\begin{tabular}{cc}
\hline Aspek Kriteria & Kriteria \\
\hline Bahasa Indonesia & C1 \\
\hline Bahasa Inggris & C2 \\
\hline Matematika & C3 \\
\hline IPA & C4 \\
\hline UN & C5 \\
\hline
\end{tabular}

Menjelaskan tentang kriteria penilaian yang ada di SMA Negeri 1 Bawang, sebagai acuan penentuan penjurusan siswa.

\section{B. Bobot Penilaian}

Pemberian bobot pada setiap kriteria sebagai berikut:

1. Nilai Bobot Bahasa Indonesia

Tabel 2. Bobot Penilaian Bahasa Indonesia

\begin{tabular}{ccc}
\hline Nilai & Bobot & Keterangan \\
\hline $9.30-11.25$ & 5 & Sangat Penting \\
\hline $7.30-9.25$ & 4 & Penting \\
\hline $5.30-7.25$ & 3 & Cukup Penting \\
\hline $3.30-5.25$ & 2 & Kurang Penting \\
\hline $1.25-3.25$ & 1 & Sangat Kurang Penting \\
\hline
\end{tabular}

Merupakan kriteria nilai bobot yang berfungsi untuk dapat mengukur kriteria bahasa indonesia yang sudah ditentukan

2. Nilai Bobot Bahasa Inggris

Tabel 3. Bobot Penilaian Bahasa Inggris

Nilai Bobot Keterangan

\begin{tabular}{ccc}
\hline $9.30-11.25$ & 5 & Sangat Penting \\
\hline $7.30-9.25$ & 4 & Penting \\
\hline $5.30-7.25$ & 3 & Cukup Penting \\
\hline $3.30-5.25$ & 2 & Kurang Penting \\
\hline $1.25-3.25$ & 1 & $\begin{array}{c}\text { Sangat Kurang } \\
\text { Penting }\end{array}$ \\
\hline
\end{tabular}

Merupakan kriteria nilai bobot yang berfungsi untuk dapat mengukur kriteria bahasa inggris yang sudah ditentukan

3. Nilai Bobot Matematika

Tabel 4. Bobot Penilaian Matematika

\begin{tabular}{ccc}
\hline Nilai & Bobot & Keterangan \\
\hline $9.30-11.25$ & 5 & Sangat Penting \\
\hline $7.30-9.25$ & 4 & Penting \\
\hline $5.30-7.25$ & 3 & Cukup Penting \\
\hline $3.30-5.25$ & 2 & Kurang Penting \\
\hline $1.25-3.25$ & 1 & Sangat Kurang Penting \\
\hline
\end{tabular}

Merupakan kriteria nilai bobot yang berfungsi untuk dapat mengukur kriteria matematika yang sudah ditentukan

4. Nilai Bobot IPA

Tabel 5. Bobot Penilaian IPA

\begin{tabular}{ccc}
\hline Nilai & Bobot & Keterangan \\
\hline $9.30-11.25$ & 5 & Sangat Penting \\
\hline $7.30-9.25$ & 4 & Penting \\
\hline $5.30-7.25$ & 3 & Cukup Penting \\
\hline $3.30-5.25$ & 2 & Kurang Penting \\
\hline $1.25-3.25$ & 1 & Sangat Kurang Penting \\
\hline
\end{tabular}

Merupakan kriteria nilai bobot yang berfungsi untuk dapat mengukur kriteria IPA yang sudah ditentukan

5. Nilai Bobot Ujian Nasional

Tabel 6. Bobot Penilaian Ujian Nasional

\begin{tabular}{ccc}
\hline Nilai & Bobot & Keterangan \\
\hline $31.60-35.50$ & 5 & Sangat Penting \\
\hline $27.60-31.50$ & 4 & Penting \\
\hline $23.60-27.50$ & 3 & Cukup Penting \\
\hline $19.60-23.50$ & 2 & Kurang Penting \\
\hline $15.50-19.50$ & 1 & Sangat Kurang Penting \\
\hline
\end{tabular}

Merupakan kriteria nilai bobot yang berfungsi untuk dapat mengukur kriteria ujian nasional yang sudah ditentukan

6. Nilai Bobot Setiap Kriteria

Tabel 7. Bobot Penilaian Setiap Kriteria

\begin{tabular}{ccc}
\hline Kriteria & \multicolumn{2}{c}{ Jurusan } \\
\cline { 2 - 3 } & IPA & IPS \\
\hline C1= Bahasa Indonesia & 4 & 4 \\
\hline C2= Bahasa Inggris & 4 & 4 \\
\hline
\end{tabular}




\begin{tabular}{cll}
\hline C3= Matematika & 5 & 5 \\
\hline C4= IPA & 5 & 4 \\
\hline C5= UN & 5 & 5 \\
\hline
\end{tabular}

Merupakan kriteria nilai bobot yang berfungsi untuk dapat mengukur setiap kriteria yang sudah ditentukan pada setiap jurusan.

\section{Data Sekunder}

Data sekunder adalah data yang di dapat dan digunakan oleh peneliti berasal dari lembaga tertentu. Lembaga ini bisa berupa apaan juga, seperti Biro Pusat Statitistik, Bank Indonesia atau lembaga penyedia data lainnya.

Data nilai ujian nasional SMP ini di dapatkan dari SMA Negeri 1 Bawang pada bagian tata usaha, setiap siswa yang ingin mendaftar di SMA Negeri 1 Bawang diwajibkan menyerahkan data nilai ujian nasional SMP sebagai syarat pendaftaran dan data tersebut di olah dan dikumpulkan oleh bagian tata usaha dengan tujuan untuk menentukan jurusan masing-masing siswa. Adapun sampel yang ditampilkan dari data 1 sampai 10 dan 61 sebagai berikut:

Tabel 8. Data Nilai SMA Negeri 1 Bawang

\begin{tabular}{lllllll}
\hline NO & \multicolumn{1}{c}{ NAMA } & IND & ING & MTK & IPA & NUN \\
\hline & $\begin{array}{l}\text { RULITA LAILAN } \\
1\end{array}$ & & & & & \\
& FAJRIN & 8.60 & 5.60 & 9.25 & 6.50 & 29.95 \\
\hline & $\begin{array}{l}\text { ILMA YANG } \\
\text { FAUNI }\end{array}$ & 8.80 & 7.20 & 6.50 & 6.25 & 28.75 \\
\hline & $\begin{array}{l}\text { NATA } \\
\text { SYAFAATUL }\end{array}$ & & & & & \\
3 & UDHMA & 7.80 & 5.20 & 8.50 & 7.25 & 28.75 \\
\hline & ILMA & & & & & \\
4 & FITRIYANA & 9.20 & 6.20 & 7.25 & 5.25 & 27.90 \\
\hline & MAYA & & & & & \\
5 & WULANDARI & 7.60 & 4.80 & 8.00 & 5.00 & 25.40 \\
\hline 6 & HENI EKAWATI & 8.40 & 7.20 & 5.00 & 6.25 & 26.85 \\
\hline 7 & MELSHA & & & & & \\
& YUNITA & 7.40 & 6.60 & 7.00 & 5.00 & 26.00 \\
\hline 8 & YENI NUR ASIH & 9.20 & 5.00 & 7.00 & 5.50 & 26.70 \\
\hline & SITORESMI & & & & & \\
9 & IDAYANI & 8.40 & 7.00 & 4.75 & 6.50 & 26.65 \\
\hline & OLIVIA & & & & & \\
10 & HAPSARI & 8.20 & 4.80 & 5.75 & 6.00 & 24.75 \\
\hline & ANTONIUS & & & & & \\
61 & FELIK & 7.25 & 5.25 & 5.00 & 3.25 & 20.75 \\
\hline & & & & & &
\end{tabular}

TOPSIS menggunakan prinsip bahwa alternatif yang terpilih harus mempunyai jarak terdekat dari solusi ideal positif dan jarak terpanjang (terjauh) dari solusi ideal negatif dari sudut pandang geometris dengan menggunakan jarak euclidean (jarak antara dua titik) untuk menentukan kedekatan relatif dar suatu alternatif (Nofriansyah, 2014)

\section{Langkah Penyelesaian Metode TOPSIS}

\section{A. Membuat matriks keputusan

$$
V_{i j}=w_{i} r_{i j}
$$
ternormalisasi.

$$
r i j=\frac{\mathrm{xij}}{\sqrt{\sum_{i=1}^{\sum^{x 2 i}}}}
$$

Keterangan:

rij = matrik ternormalisasi $[\mathrm{i}][\mathrm{j}]$

$\mathrm{xij}=$ matrik keputusan $[\mathrm{i}][\mathrm{j}]$

$$
\begin{aligned}
& \mathrm{R}_{11}=\frac{\mathrm{X}_{11}}{\sqrt{\mathrm{X}_{11}+\mathrm{X}_{21}+\mathrm{X}_{31}+\mathrm{X}_{41}+\mathrm{X}_{51}+\cdots \mathrm{n}}} \\
& |X 1|=\sqrt{4^{2}}+3^{2}+4^{2}+3^{2}+4^{2}=8,124
\end{aligned}
$$

$r_{11}=\frac{X_{11}}{X_{1}}=\frac{4}{8,124}=0,492$

$r_{21}=\frac{X_{21}}{X_{1}}=\frac{3}{8,124}=0,369$

$r_{31}=\frac{X_{31}}{X_{1}}=\frac{4}{8,124}=0,492$

$r_{41}=\frac{X_{41}}{X_{1}}=\frac{3}{8,124}=0,369$

$r_{51}=\frac{X_{51}}{X_{1}}=\frac{4}{8,124}=0,492$

Tabel.9 Hasil Perhitungan MatriksTernormalisasi

\begin{tabular}{cccccc}
\hline NO & C1 & C2 & C3 & C4 & C5 \\
\hline 1 & 0,492 & 0,369 & 0,492 & 0,369 & 0,492 \\
\hline 2 & 0,544 & 0,272 & 0,408 & 0,408 & 0,544 \\
\hline 3 & 0,512 & 0,256 & 0,512 & 0,384 & 0,512 \\
\hline 4 & 0,544 & 0,408 & 0,408 & 0,272 & 0,544 \\
\hline 5 & 0,571 & 0,286 & 0,571 & 0,286 & 0,429 \\
\hline 6 & 0,583 & 0,438 & 0,292 & 0,438 & 0,438 \\
\hline 7 & 0,583 & 0,438 & 0,438 & 0,292 & 0,438 \\
\hline 8 & 0,583 & 0,292 & 0,438 & 0,438 & 0,438 \\
\hline 9 & 0,583 & 0,438 & 0,292 & 0,438 & 0,438 \\
\hline 10 & 0,583 & 0,292 & 0,438 & 0,438 & 0,438 \\
\hline 61 & 0,640 & 0,426 & 0,426 & 0,213 & 0,426 \\
\hline
\end{tabular}

Merupakan Hasil perhitungan dari matriks keputusan yang ternormalisasi dari data siswa berjumlah 61 orang dan yang ditampilkan hanya dari data ke 1 sampai ke 10 dan 61.

\section{B. Membuat matriks keputusan yang ternormalisasi terbobot $\mathrm{V}$}

Selanjutnya menghitung proses ternormalisasi $\mathrm{V}$, dimana setiap alternatif diambil berdasarkan nilai dari kriteria nilai bobot dikali dengan kriteria hasil normaliasasi. Rumus nilai matriks keputusan ternormalisasi terbobot $\mathrm{V}$ diambil berdasarkan:

dengan $i=1,2 \ldots . ., m ;$ dan $j=1,2, \ldots . . n$. 
$\mathrm{V}_{\mathrm{ij}}=$ Elemen dari matriks keputusan yang ternormalisasi terbobot $\mathrm{V}$

$\mathrm{W}_{\mathrm{i}}=\quad$ Bobot dari kriteria ke-j

$\mathrm{r}_{\mathrm{ij}}=$ Elemen matriks keputusan yang ternormalisasi R.

1. Jurusan IPA

$$
\begin{aligned}
& V 1 \cdot 1=W 1 \cdot R 11=4 \times 0,492=1,969 \\
& V 2 \cdot 1=W 1 \cdot R 21=4 \times 0,369=1,477 \\
& V 3 \cdot 1=W 1 \cdot R 31=5 \times 0,492=2,462 \\
& V 4 \cdot 1=W 1 \cdot R 41=5 \times 0,369=1,846 \\
& V 5 \cdot 1=W 1 \cdot R 51=5 \times 0,492=2,462
\end{aligned}
$$

Tabel.10 Hasil Perhitungan Ternormalisasi Dengan Bobot V Jurusan IPA

\begin{tabular}{cccccc}
\hline NO & C1 & C2 & C3 & C4 & C5 \\
\hline 1 & 1,969 & 1,477 & 2,462 & 1,846 & 2,462 \\
\hline 2 & 2,177 & 1,089 & 2,041 & 2,041 & 2,722 \\
\hline 3 & 2,049 & 1,024 & 2,561 & 1,921 & 2,561 \\
\hline 4 & 2,177 & 1,633 & 2,041 & 1,361 & 2,722 \\
\hline 5 & 2,286 & 1,143 & 2,857 & 1,429 & 2,143 \\
\hline 6 & 2,334 & 1,750 & 1,459 & 2,188 & 2,188 \\
\hline 7 & 2,334 & 1,750 & 2,188 & 1,459 & 2,188 \\
\hline 8 & 2,334 & 1,167 & 2,188 & 2,188 & 2,188 \\
\hline 9 & 2,334 & 1,750 & 1,459 & 2,188 & 2,188 \\
\hline 10 & 2,334 & 1,167 & 2,188 & 2,188 & 2,188 \\
\hline 61 & 2,558 & 1,706 & 2,132 & 1,066 & 2,132 \\
\hline
\end{tabular}

Merupakan Hasil perhitungan Ternormalisasi Dengan Bobot V Jurusan IPA dari data siswa berjumlah 61 orang dan yang ditampilkan hanya dari data ke 1 sampai ke 10 dan 61.

2. Jurusan IPS

$$
\begin{aligned}
& V 1 \cdot 1=W 1 \cdot R 11=4 \times 0,492=1,969 \\
& V 2 \cdot 1=W 1 \cdot R 21=4 \times 0,369=1,477 \\
& V 3 \cdot 1=W 1 \cdot R 31=5 \times 0,492=2,462 \\
& V 4 \cdot 1=W 1 \cdot R 41=4 \times 0,369=1,477 \\
& V 5 \cdot 1=W 1 \cdot R 51=5 \times 0,492=2,462
\end{aligned}
$$

Tabel.11 Hasil Perhitungan Ternormalisasi Dengan Bobot V Jurusan IPS

\begin{tabular}{cccccc}
\hline N0 & C1 & C2 & C3 & C4 & C5 \\
\hline 1 & 1,969 & 1,477 & 2,462 & 1,477 & 2,462 \\
\hline 2 & 2,177 & 1,089 & 2,041 & 1,633 & 2,722 \\
\hline 3 & 2,049 & 1,024 & 2,561 & 1,536 & 2,561 \\
\hline 4 & 2,177 & 1,633 & 2,041 & 1,089 & 2,722 \\
\hline 5 & 2,286 & 1,143 & 2,857 & 1,143 & 2,143 \\
\hline 6 & 2,334 & 1,750 & 1,459 & 1,750 & 2,188 \\
\hline 7 & 2,334 & 1,750 & 2,188 & 1,167 & 2,188 \\
\hline 8 & 2,334 & 1,167 & 2,188 & 1,750 & 2,188 \\
\hline 9 & 2,334 & 1,750 & 1,459 & 1,750 & 2,188 \\
\hline 10 & 2,334 & 1,167 & 2,188 & 1,750 & 2,188 \\
\hline 61 & 2,558 & 1,706 & 2,132 & 0,853 & 2,132 \\
\hline
\end{tabular}

Merupakan Hasil perhitungan Ternormalisasi Dengan Bobot V Jurusan IPS dari data siswa berjumlah 61 orang dan yang ditampilkan hanya dari data ke 1 sampai ke 10 dan 61.

\section{Solusi ideal positif $\mathrm{A}^{+}$dan solusi ideal negatif $A^{-}$}

$A^{+}=\left(Y_{1}^{+}, Y_{2}^{+}, \ldots . Y_{n}^{+}\right.$
$A^{-}=\left(Y_{1}^{-}, Y_{2}^{-}, \ldots . Y_{n}^{-}\right.$

Keterangan:

$\mathrm{V}_{\mathrm{j}}=\max _{\mathrm{ij}}$, jika $\mathrm{j}$ adalah atribut keuntungan

Min $Y_{\mathrm{ij}}$, jika $\mathrm{j}$ adalah atribut biaya

1. Jurusan IPA

Tabel 12. Solusi ideal positif $\mathrm{A}^{+}$dan solusi ideal

\begin{tabular}{cccccc}
\multicolumn{6}{c}{ negatif $\mathrm{A}^{-}$} \\
\hline IPA & C1 & C2 & C3 & C4 & C5 \\
\hline A+ & 3,336 & 2,449 & 2,857 & 2,739 & 2,722 \\
\hline A- & 1,696 & 0,834 & 0,700 & 0,737 & 0,981 \\
\hline
\end{tabular}

Merupakan Hasil Solusi ideal positif $\mathrm{A}^{+}$dan solusi ideal negatif $A^{-}$pada jurusan IPA dilihat dari semua data ke 1 sampai ke 61 . Pada $\mathrm{A}^{+}$dilihat nilai yang paling besar pada setiap kriteria sedangkan pada $\mathrm{A}^{-}$dilihat nilai paling kecil pada setiap kriteria

\section{Jurusan IPS}

Tabel 13. Solusi ideal positif $\mathrm{A}^{+}$dan solusi ideal

\begin{tabular}{cccccc}
\multicolumn{7}{c}{ negatif $A^{-}$} \\
\hline IPS & C1 & C2 & C3 & C4 & C5 \\
\hline A+ & 3,336 & 2,449 & 2,857 & 2,191 & 2,722 \\
\hline$A^{-}$ & 1,696 & 0,834 & 0,700 & 0,590 & 0,981
\end{tabular}

Merupakan Hasil Solusi ideal positif $\mathrm{A}^{+}$dan solusi ideal negatif $A^{-}$pada jurusan IPS dilihat dari semua data ke 1 sampai ke 61 . Pada $\mathrm{A}^{+}$dilihat nilai yang paling besar pada setiap kriteria sedangkan pada $A^{-}$dilihat nilai paling kecil pada setiap kriteria

\section{Perhitungan Jarak $A_{i}$ dengan Solusi Ideal Positif $\mathrm{D}^{+}$dan Solusi Ideal Negatif $\mathrm{D}^{-}$}

$D i^{+}=\sqrt{\sum_{j=n}^{n}\left(Y_{i j}-Y_{j}^{+}\right)^{2}}$

Keterangan:

$\mathrm{D}_{\mathrm{i}}^{+}=$Jarak alternatif Ai dengan solusi ideal positif

$\mathrm{Y}_{\mathrm{j}}^{+}=$Solusi ideal positif [i]

$\mathrm{Y}_{\mathrm{ij}}=$ Matriks normalisasi $[\mathrm{i}][\mathrm{j}]$

1. Perhitungan Solusi Ideal Positif $\mathrm{D}^{+}$Jurusan IPA 


$$
\begin{gathered}
D_{1}^{+}=\sqrt[\begin{array}{c}
(1,969-3,336)^{2}+(1,477-2,449)^{2} \\
+(2,462-2,857)^{2}+(1,846-2,739)^{2} \\
+(2,462-2,722)^{2}=3,833
\end{array}]{\begin{array}{c}
(2,177-3,336)^{2}+(1,089-2,449)^{2} \\
+(2,041-2,857)^{2}+(2,041-2,739)^{2} \\
+(2,722-2,722)^{2}=4,345
\end{array}} \\
D_{2}^{+}=\sqrt{\begin{array}{c}
(2,049-3,336)^{2}+(1,024-2,449)^{2} \\
+(2,561-2,857)^{2}+(1,921-2,739)^{2} \\
+(2,561-2,722)^{2}=4,471
\end{array}} \\
D_{3}^{+}=\sqrt{\begin{array}{c}
(2,177-3,336)^{2}+(1,633-2,449)^{2} \\
+(2,041-2,857)^{2}+(1,361-2,739)^{2} \\
+(2,722-2,722)^{2}=4,573
\end{array}} \\
D_{4}^{+}=\sqrt{\begin{array}{c}
(2,286-3,336)^{2}+(1,143-2,449)^{2} \\
+(2,857-2,857)^{2}+(1,429-2,739)^{2} \\
+(2,143-2,722)^{2}=4,862
\end{array}}
\end{gathered}
$$

2. Perhitungan Solusi Ideal Positif D-Jurusan IPA

$$
\begin{aligned}
& D_{1}^{-}=(1,969-1,969)^{2}+(1,477-0,834)^{2}
\end{aligned}
$$

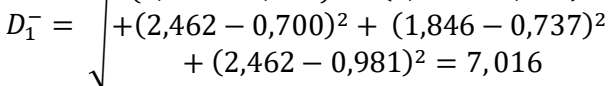

$$
\begin{aligned}
& D_{2}^{-}=\sqrt{\begin{array}{c}
(2,177-1,696)^{2}+(1,089-0,834)^{2} \\
+(2,041-0,700)^{2}+(2,041-0,737)^{2} \\
+(2,722-0,981)^{2}=6,826
\end{array}} \\
& D_{3}^{-}=\begin{array}{c}
(2,049-1,696)^{2}+(1,024-0,834)^{2} \\
+(2,561-0,700)^{2}+(1,921-0,737)^{2}
\end{array} \\
& +(2,561-0,981)^{2}=7,519 \\
& (2,177-1,696)^{2}+(1,633-2,449)^{2} \\
& D_{4}^{-}=\quad+(2,041-0,700)^{2}+(1,361-0,737)^{2} \\
& +(2,722-0,981)^{2}=6,088 \\
& (2,286-1,696)^{2}+(1,143-2,449)^{2} \\
& D_{5}^{-}=\sqrt{\begin{array}{c}
(2,286-1,696)^{2}+(1,143-2,449)^{2} \\
+(2,857-0,700)^{2}+(1,429-0,737)^{2} \\
+(2,143-0,981)^{2}=6,925
\end{array}}
\end{aligned}
$$

Tabel 15. Hasil Perhitungan Solusi Ideal Positif $\mathrm{D}^{+}$ dan Positif D-Jurusan IPA

\begin{tabular}{llll}
\hline NO & NAMA & Di+ & Di- \\
\hline 1 & RULITA LAILAN FAJRIN & 3,833 & 7,016 \\
\hline 2 & ILMA YANG FAUNI & 4,345 & 6,826 \\
\hline 3 & NATA SYAFAATUL UDHMA & 4,471 & 7,519 \\
\hline 4 & ILMA FITRIYANA & 4,573 & 6,088 \\
\hline 5 & MAYA WULANDARI & 4,862 & 6,925 \\
\hline 6 & HENI EKAWATI & 4,037 & 5,384 \\
\hline 7 & MELSHA YUNITA & 3,864 & 5,438 \\
\hline 8 & YENI NUR ASIH & 3,684 & 6,294 \\
\hline 9 & SITORESMI IDAYANI & 4,037 & 5,384 \\
\hline 10 & OLIVIA HAPSARI & 3,684 & 6,294 \\
\hline 61 & ANTONIUS FELIK & 4,830 & 4,987 \\
\hline
\end{tabular}

Merupakan hasil perhitungan solusi ideal positif $\mathrm{D}^{+}$dan solusi ideal negatif $\mathrm{D}^{-}$pada jurusan IPA dilihat dari semua data ke 1 sampai ke 61.

3. Perhitungan Solusi Ideal Positif $\mathrm{D}^{+}$Jurusan IPS

$$
\begin{aligned}
& D_{1}^{+}=\sqrt{\begin{array}{c}
(1,969-3,336)^{2}+(1,477-2,449)^{2} \\
+(2,462-2,857)^{2}+(1,447-2,191)^{2} \\
+(2,462-2,722)^{2}=3,833
\end{array}} \\
& D_{2}^{+}=\sqrt{\begin{array}{c}
(2,177-3,336)^{2}+(1,089-2,449)^{2} \\
+(2,041-2,857)^{2}+(1,633-2,191)^{2} \\
+(2,722-2,722)^{2}=4,345
\end{array}} \\
& D_{3}^{+}=\sqrt{\begin{array}{c}
(2,049-3,336)^{2}+(1,024-2,449)^{2} \\
+(2,561-2,857)^{2}+(1,536-2,191)^{2} \\
+(2,561-2,722)^{2}=4,471
\end{array}} \\
& D_{4}^{+}=\sqrt{\begin{array}{c}
(2,177-3,336)^{2}+(1,633-2,449)^{2} \\
+(2,041-2,857)^{2}+(1,089-2,191)^{2} \\
+(2,722-2,722)^{2}=4,573
\end{array}} \\
& D_{5}^{+}=\sqrt{\begin{array}{c}
(2,286-3,336)^{2}+(1,143-2,449)^{2} \\
+(2,857-2,857)^{2}+(1,143-2,191)^{2} \\
+(2,143-2,722)^{2}=4,862
\end{array}}
\end{aligned}
$$

4. Perhitungan Solusi Ideal Positif $\mathrm{D}^{+}$Jurusan IPS

$$
\begin{aligned}
& D_{1}^{-}=\sqrt{\begin{array}{c}
(1,969-1,969)^{2}+(1,477-0,834)^{2} \\
+(2,462-0,700)^{2}+(1,477-0,590)^{2} \\
+(2,462-0,981)^{2}=6,572
\end{array}} \\
& D_{2}^{-}=\sqrt{\begin{array}{c}
(2,177-1,696)^{2}+(1,089-0,834)^{2} \\
+(2,041-0,700)^{2}+(1,633-0,590)^{2} \\
+(2,722-0,981)^{2}=6,213
\end{array}} \\
& D_{3}^{-}=\sqrt{\begin{array}{c}
(2,049-1,696)^{2}+(1,024-0,834)^{2} \\
+(2,561-0,700)^{2}+(1,536-0,590)^{2} \\
+(2,561-0,981)^{2}=7,014
\end{array}} \\
& D_{4}^{-}=\sqrt{\begin{array}{c}
(2,177-1,696)^{2}+(1,633-2,449)^{2} \\
+(2,041-0,700)^{2}+(1,089-0,590)^{2} \\
+(2,722-0,981)^{2}=5,551
\end{array}} \\
& D_{5}^{-}=\sqrt{\begin{array}{c}
(2,286-1,696)^{2}+(1,143-2,449)^{2} \\
+(2,857-0,700)^{2}+(1,143-0,590)^{2} \\
+(2,143-0,981)^{2}=6,526
\end{array}}
\end{aligned}
$$

Tabel 16. Hasil Perhitungan Solusi Ideal Positif D ${ }^{+}$ dan Positif D- Jurusan IPS

\begin{tabular}{llll}
\hline NO & NAMA & Di+ & Di- \\
\hline 1 & RULITA LAILAN FAJRIN & 3,546 & 6,572 \\
\hline 2 & ILMA YANG FAUNI & 4,170 & 6,213 \\
\hline 3 & NATA SYAFAATUL UDHMA & 4,229 & 7,014 \\
\hline 4 & ILMA FITRIYANA & 3,889 & 5,551 \\
\hline 5 & MAYA WULANDARI & 4,243 & 6,526 \\
\hline 6 & HENI EKAWATI & 3,927 & 4,625 \\
\hline 7 & MELSHA YUNITA & 3,274 & 5,002 \\
\hline 8 & YENI NUR ASIH & 3,575 & 5,535 \\
\hline 9 & SITORESMI IDAYANI & 3,927 & 4,625 \\
\hline 10 & OLIVIA HAPSARI & 3,575 & 5,535 \\
\hline 61 & ANTONIUS FELIK & 3,822 & 4,662
\end{tabular}

Merupakan hasil perhitungan solusi ideal positif $\mathrm{D}^{+}$dan solusi ideal negatif $\mathrm{D}^{-}$pada jurusan IPS dilihat dari semua data ke 1 sampai ke 61.

\section{E. Nilai preferensi untuk setiap alternatif $\left(V_{i}\right)$}


$V_{i}=\frac{D_{i-}}{D_{i-+}+D_{i+}}$

$\mathrm{i} \quad=1,2, \ldots \mathrm{m}$

$\mathrm{Vi}=$ Kedekatan tiap alternatif terhadap solusi ideal

$\mathrm{D}_{\mathrm{i}}{ }^{+}=$Jarak alternatif Ai dengan solusi ideal positif

$\mathrm{D}_{\mathrm{i}}{ }^{-}=$Jarak alternatif Ai dengan solusi ideal negatif

Nilai $V_{i}$ yang lebih besar menunjukan bahwa alternatif $A_{i}$ lebih dipilih.

1. Perhitungan Nilai preferensi untuk setiap alternatif $\left(\mathrm{V}_{\mathrm{i}}\right)$ Jurusan IPA

$$
\begin{aligned}
& V_{1}=\frac{7,016}{7,016+3,833}=\frac{7,016}{10,849}=0,647 \\
& V_{2}=\frac{6,826}{6,826+4,345}=\frac{6,826}{11,172}=0,611 \\
& V_{3}=\frac{7,519}{7,519+4,471}=\frac{7,519}{11,990}=0,627 \\
& V_{4}=\frac{6,088}{6,088+4,573}=\frac{6,088}{10,661}=0,571 \\
& V_{5}=\frac{6,925}{6,925+4,862}=\frac{6,925}{11,786}=0,588
\end{aligned}
$$

Tabel 17. Hasil Perhitungan Nilai preferensi untuk setiap alternatif $\left(\mathrm{V}_{\mathrm{i}}\right)$ Jurusan IPA

\begin{tabular}{clc}
\hline No & \multicolumn{1}{c}{ Nama } & $\mathbf{V}_{\mathbf{i}}$ \\
\hline 1 & RULITA LAILAN FAJRIN & 0,647 \\
\hline 2 & ILMA YANG FAUNI & 0,611 \\
\hline 3 & NATA SYAFAATUL UDHMA & 0,627 \\
\hline 4 & ILMA FITRIYANA & 0,571 \\
\hline 5 & MAYA WULANDARI & 0,588 \\
\hline 6 & HENI EKAWATI & 0,572 \\
\hline 7 & MELSHA YUNITA & 0,585 \\
\hline 8 & YENI NUR ASIH & 0,631 \\
\hline 9 & SITORESMI IDAYANI & 0,572 \\
\hline 10 & OLIVIA HAPSARI & 0,631 \\
\hline 61 & ANTONIUS FELIK & 0,508 \\
\hline
\end{tabular}

Merupakan hasil Perhitungan Nilai preferensi untuk setiap alternatif $\left(\mathrm{V}_{\mathrm{i}}\right)$ pada Jurusan IPA dilihat dari semua data ke 1 sampai ke 61.

2. Perhitungan Nilai preferensi untuk setiap alternatif $\left(\mathrm{V}_{\mathrm{i}}\right)$ Jurusan IPS

$$
\begin{aligned}
& V_{1}=\frac{6,572}{6,572+3,546}=\frac{6,572}{10,118}=0,650 \\
& V_{2}=\frac{6,213}{6,213+4,170}=\frac{6,213}{10,383}=0,598 \\
& V_{3}=\frac{7,014}{7,014+4,229}=\frac{7,014}{11,244}=0,624
\end{aligned}
$$

$$
\begin{aligned}
& V_{4}=\frac{5,551}{5,551+3,889}=\frac{5,551}{9,440}=0,588 \\
& V_{5}=\frac{6,526}{6,526+4,243}=\frac{6,526}{10,769}=0,606
\end{aligned}
$$

\begin{tabular}{|c|c|c|}
\hline$V_{i}$ IPA & $V_{i}$ IPS & Hasil \\
\hline 0,647 & 0,650 & IPS \\
\hline 0,611 & 0,598 & IPA \\
\hline 0,627 & 0,624 & IPA \\
\hline 0,571 & 0,588 & IPS \\
\hline 0,588 & 0,606 & IPS \\
\hline 0,572 & 0,541 & IPA \\
\hline 0,585 & 0,604 & IPA \\
\hline 0,631 & 0,608 & IPA \\
\hline 0,572 & 0,541 & IPA \\
\hline 0,631 & 0,608 & IPA \\
\hline 0,584 & 0,607 & IPS \\
\hline 0,518 & 0,537 & IPS \\
\hline 0,572 & 0,541 & IPA \\
\hline 0,518 & 0,537 & IPS \\
\hline 0,572 & 0,533 & IPA \\
\hline 0,640 & 0,626 & IPA \\
\hline 0,640 & 0,626 & IPA \\
\hline 0,663 & 0,636 & IPA \\
\hline 0,406 & 0,441 & IPS \\
\hline 0,572 & 0,541 & IPA \\
\hline 0,585 & 0,604 & IPA \\
\hline 0,446 & 0,419 & IPA \\
\hline 0,585 & 0,604 & IPA \\
\hline 0,572 & 0,541 & IPA \\
\hline 0,585 & 0,604 & IPA \\
\hline 0,631 & 0,608 & IPA \\
\hline 0,585 & 0,616 & IPS \\
\hline 0,631 & 0,608 & IPA \\
\hline 0,518 & 0,537 & IPS \\
\hline 0,606 & 0,570 & IPA \\
\hline 0,584 & 0,607 & IPS \\
\hline 0,317 & 0,337 & IPA \\
\hline 0,317 & 0,337 & IPA \\
\hline 0,563 & 0,561 & IPA \\
\hline 0,535 & 0,508 & IPA \\
\hline
\end{tabular}

Tabel 18. Hasil Perhitungan Nilai preferensi untuk setiap alternatif $\left(\mathrm{V}_{\mathrm{i}}\right)$ Jurusan IPS

\begin{tabular}{cll}
\hline No & \multicolumn{1}{c}{ Nama } & $\mathbf{V}_{\mathbf{i}}$ \\
\hline 1 & RULITA LAILAN FAJRIN & 0,650 \\
\hline 2 & ILMA YANG FAUNI & 0,598 \\
\hline 3 & NATA SYAFAATUL UDHMA & 0,624 \\
\hline 4 & ILMA FITRIYANA & 0,588 \\
\hline 5 & MAYA WULANDARI & 0,606 \\
\hline 6 & HENI EKAWATI & 0,541 \\
\hline 7 & MELSHA YUNITA & 0,604 \\
\hline 8 & YENI NUR ASIH & 0,608 \\
\hline 9 & SITORESMI IDAYANI & 0,541 \\
\hline 10 & OLIVIA HAPSARI & 0,608 \\
\hline 61 & ANTONIUS FELIK & 0,549 \\
\hline
\end{tabular}

Merupakan hasil Perhitungan Nilai preferensi untuk setiap alternatif $\left(\mathrm{V}_{\mathrm{i}}\right)$ pada Jurusan IPS dilihat dari semua data ke 1 sampai ke 61 .

\section{Hasil Penelitian}

Tabel 19. Perbandingan Hasil Perhitungan Nilai Preferensi Setiap Alternatif $\left(V_{i}\right)$ 


\begin{tabular}{|c|c|c|}
\hline$V_{i}$ IPA & $V_{\mathrm{i}}$ IPS & Hasil \\
\hline 0,508 & 0,549 & IPS \\
\hline 0,535 & 0,508 & IPA \\
\hline 0,398 & 0,372 & IPA \\
\hline 0,430 & 0,384 & IPA \\
\hline 0,345 & 0,320 & IPA \\
\hline 0,430 & 0,384 & IPA \\
\hline 0,336 & 0,306 & IPA \\
\hline 0,445 & 0,483 & IPS \\
\hline 0,430 & 0,384 & IPA \\
\hline 0,345 & 0,320 & IPA \\
\hline 0,426 & 0,369 & IPA \\
\hline 0,627 & 0,624 & IPA \\
\hline 0,480 & 0,502 & IPS \\
\hline 0,631 & 0,608 & IPA \\
\hline 0,590 & 0,540 & IPA \\
\hline 0,487 & 0,494 & IPS \\
\hline 0,504 & 0,502 & IPS \\
\hline 0,504 & 0,502 & IPS \\
\hline 0,504 & 0,502 & IPS \\
\hline 0,504 & 0,502 & IPS \\
\hline 0,504 & 0,502 & IPS \\
\hline 0,504 & 0,502 & IPS \\
\hline 0,615 & 0,555 & IPA \\
\hline 0,563 & 0,561 & IPS \\
\hline 0,508 & 0,549 & IPS \\
\hline 0,508 & 0,549 & IPS \\
\hline
\end{tabular}

Hasil penelitian dari perbandingan hasil perhitungan nilai preferensi setiap alternatif $\left(\mathrm{V}_{\mathrm{i}}\right)$ dari 61 siswa tersebut yaitu telah ditentukan bahwa 37 siswa masuk pada jurusan IPA dan 24 Siswa masuk pada jurusan IPS.

\section{SIMPULAN DAN SARAN}

\section{Simpulan}

Hasil perhitungan dari preferensi alternatif $\mathrm{V}$ dari jurusan IPA dan IPS diperbandingkan, Apabila hasil perhitungan nilai IPA lebih besar dari pada IPS maka siswa tersebut akan masuk jurusan IPA dan Sebaliknya jika hasil perhitungan nilai IPS lebih besar dari pada IPA maka siswa tersebut akan masuk jurusan IPS Hasil perhitungan dari seluruh data sampel dengan kriteria masingmasing jurusan telah ditentukan bahwa dari 61 data sampel ada sebanyak 37 siswa yang masuk pada jurusan IPA dan 24 siswa masuk pada jurusan IPS.

\section{Saran}

Terkait dengan penelitian ini perlu dilakukan studi lebih lanjut mengenai data yang digunakan untuk penelitian, misalnya menggunakan data primer atau kueisioner yang dibagikan kepada siswa untuk menanyakan minat siswa dalam mengambil jurusan sehingga penentuan jurusan bukan hanya ditentukan dari pihak sekolah atau nilai ujian nasional. Untuk penelitian selanjutnya peneliti diharapakan membuat aplikasi penghitung cepat sederhana untuk menyempurnakan penelitian ini. Sistem Pendukung Keputusan dibangun pada SMA tersebut dapat dikembangkan dengan metode FDAM lain Seperti AHP, SAW, WP dan Profile Matching.

\section{DAFTAR REFERENSI}

Agusli, R., Dzulhaq, M. I., \& Khasanah, U. (2017). Sistem Pendukung Keputusan Pemberian Bonus Tahunan Karyawan Menggunakan Metode TOPSIS. JURNAL SISFOTEK GLOBAL.

Dashti, Z., Pedram, M. M., \& Shanbehzadeh, J. (2010). A multi-criteria decision making based method for ranking sequential patterns. Proceedings of the International MultiConference of Engineers and Computer Scientists 2010, IMECS 2010, I, 611-614.

Mardiana, T., \& Tanjung, S. S. (2019). SISTEM PENDUKUNG KEPUTUSAN PEMILIHAN PERGURUAN TINGGI SWASTA MENGGUNAKAN TOPSIS. Jurnal Riset Informatika, 1(2), 25-34. https://doi.org/10.34288/jri.v1i2.30

Nofriansyah, D. (2014). Konsep Data Mining Vs Sistem Pendukung Keputusan. Deepublish.

Prayoga, B. S., \& Pradnya, W. M. (2017). SISTEM PENDUKUNG KEPUTUSAN JURUSAN DI MAN II YOGYAKARTA MENGGUNAKAN ALGORITMA TOPSIS. SEMNASTEKNOMEDIA ONLINE, 5(1), 55-60.

Siyoto, S., \& Sodik, M. A. (2015). Dasar Metodologi Penelitian. Literasi Media Publishing.

Susliansyah, S., Rahadjeng, I. R., Sumarno, H., \& Deleaniara. M, C. M. (2019). PENERAPAN METODE TOPSIS DALAM PENILAIAN KINERJA GURU TETAP SD NEGERI KEBALEN 07. Jurnal Pilar Nusa Mandiri, 15(1), 7-14. https://doi.org/10.33480/pilar.v15i1.2 